\title{
Farewell to Mihály Beck
}

\author{
Gábor Lente ${ }^{1}$
}

Received: 16 August 2017/Accepted: 16 August 2017/Published online: 20 August 2017

(C) Akadémiai Kiadó, Budapest, Hungary 2017

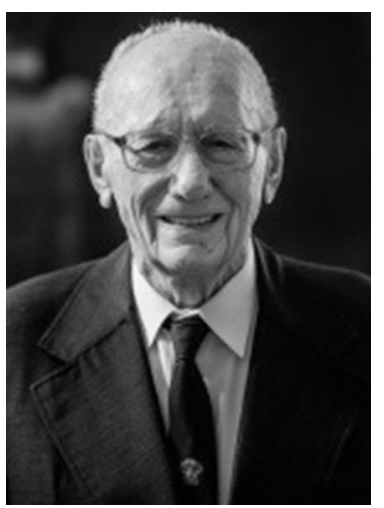

It is my sad duty to inform the readers of Reaction Kinetics Mechanisms and Catalysis that Mihály T. Beck, known as Miska to his friends, passed away on July 31, 2017. He was 87.

His name was displayed in the Editorial Board beginning in the very first issue published in 1974 (then under the title Reaction Kinetics and Catalysis Letters) as a joint venture of the Hungarian and Soviet Academies of Science. So his tenure on the board extended to 43 years - almost half a century. Between 1974 and 1992, he co-authored nine articles in this journal.

Mihály Beck was born on November 14, 1929 in a village called Szőreg, today part of the town of Szeged. He obtained his doctorate from the University of Szeged

Gábor Lente

rkcl@science.unideb.hu

1 Editorial Office, Reaction Kinetics, Mechanisms and Catalysis, Department of Inorganic and Analytical Chemistry, University of Debrecen, Debrecen, Hungary 
in 1957 and became a full professor there in 1965. He was invited to head the Department of Physical Chemistry at the Lajos Kossuth University in Debrecen in 1968, which turned out to be another long tenure lasting 22 years. He became a member of the Hungarian Academy of Sciences in 1973. He spent some time as a visiting professor in 1981 at the University of Leeds. In 1983-1984, he toured the US as a Fulbright scholar with Princeton and Georgetown being the main assignments. For some years, he also served as vice-rector and rector at his home institution, and was the head of the Section of Chemical Sciences at the Hungarian Academy of Sciences from 1976 to 1985 . From the sixties to the eighties, he held various positions at the International Union of Pure and Applied Chemistry. He was an honorary member of the Finnish Academy of Science and Letters and the Mediterranean Academy of Sciences.

Mihály Beck's first field of scientific interest was coordination chemistry. He developed several new methods for determining stability constants, discovered the basic principles governing species distributions in complex equilibria and explored the defining role of certain metal complexes in pre-biotic evolution. His book on this topic, co-authored by István Nagypál (Chemistry of Complex Equilibria, Van Nostrand Reinhold Co, 1970) is still very frequently cited. His research portfolio grew gradually wider and the main emphasis shifted to chemical kinetics in the 1970s. He was instrumental at finding large amplitude $\mathrm{pH}$ oscillations and studying the effect of microwaves on reactions was also a central topic to him. Among the numerous prizes and awards bestowed upon him, the Academy's gold award stands out. When he received this ultimate acknowledgement of scientific achievement during the open ceremonial session of the 187th General Assembly of the Hungarian Academy of Sciences in 2016, Ferenc Joó, his former student and fellow board member at this journal, noticed: "He did not get bogged down on one topic, he constantly sought new areas to study and he had a nose for what was new and important".

Mihály Beck's full publication list includes close to 500 items. About half of these are original research articles, including five papers published in Nature. He was named as a co-inventor in 23 patents, the most significant being "Suntest", a simple device for measuring the intensity of sunlight, which was commercialized in Hungary in the 1990s. The remaining publications reflect on a second full career: that of a prolific popular science writer and self-taught science historian. His last book titled Humor in Science was published in 2010 and gave vivid testament to the fact that his intellect never grew old.

I remember my first meeting with Nobel laureate Henry Taube in 1999. When he realized that I was form Hungary, his next remark was mentioning how much he admired the work of Miska Beck. In hindsight, his major achievement was to find a way to be engaged in internationally outstanding science within the very limited financial means available in Hungary during 1960s or 1970s. It must have taken a very sharp mind and enormous creativity to do this.

The personal contribution of Mihály Beck will be greatly missed in science. Yet his memory and legacy will live on not only in his publications, but also through the generations of scientists he helped to train. 